\title{
Determination of ochratoxin A in organic and non-organic cereals and cereal products from Spain and Portugal
}

\author{
C. Juan ${ }^{\text {b,* }}$, J.C. Moltó ${ }^{\mathrm{b}}$, C.M. Lino ${ }^{\mathrm{a}}$, J. Mañes ${ }^{\mathrm{b}}$ \\ ${ }^{a}$ Group of Bromatology - CEF, Faculty of Pharmacy, University of Coimbra, Portugal \\ ${ }^{\mathrm{b}}$ Laboratory of Food Chemistry and Toxicology, Faculty of Pharmacy, University of Valencia, Burjassot, Spain
}

Received 19 November 2006; received in revised form 27 June 2007; accepted 7 August 2007

\begin{abstract}
The objective of this work was to know the occurrence of OTA in organic and non-organic cereals and cereal products from Spain and Portugal. A method based on extraction with matrix solid phase dispersion (MSPD) using octylsilica $\left(\mathrm{C}_{8}\right)$ followed by liquid chromatography coupled with fluorescence detection (LC-FD) was used to determine OTA from the selected samples. Recoveries of OTA from the studied samples spiked at $10 \mathrm{ng} / \mathrm{g}$ level ranged from $78 \%$ to $89 \%$ with a standard deviation of 3.66 . The limits of detection and quantification of this method were 0.05 and $0.19 \mathrm{ng} / \mathrm{g}$, respectively. Furthermore, LC-FD after OTA methylation was used to confirm the identity of OTA in all positive samples. This procedure was applied to 83 organic and non-organic samples including rice, wheat, barley, rye, oats and maize from Spain and Portugal. OTA was detected in $22 \%$ of the samples, with concentrations ranging from 0.20 to $27.10 \mathrm{ng} / \mathrm{g}$. From the total OTA contaminated samples $(n=18), 72 \%$ were organic cereal and $28 \%$ were non-organic cereal samples, with mean concentrations of 1.64 and $0.05 \mathrm{ng} / \mathrm{g}$, respectively. The $66 \%$ and $34 \%$ of contaminated samples were from Spain and Portugal, respectively, with mean concentrations of 0.93 and $0.64 \mathrm{ng} / \mathrm{g}$ for each country. Six contaminated samples exceeded the maximum limits (ML) for OTA fixed by European Commission Regulation $(5 \mu \mathrm{g} / \mathrm{kg})$, among them three were from Spain and three from Portugal.
\end{abstract}

(c) 2007 Published by Elsevier Ltd.

Keywords: Cereal; Organic; Non-organic; Ochratoxin A; Portugal; Spain

\section{Introduction}

Ochratoxin A (OTA) is a fungal secondary metabolite which has been described as carcinogenic, teratogenic and a potent nephrotoxic. Immunotoxic and carcinogenic properties in rats and humans, respectively, have been reported (group 2B) (IARC, 1993). OTA has been extensively documented as a global contaminant of a wide variety of foods such as cereal, cereal products, nuts, spices, grapes, beer and wine (Blesa, Berrada, Soriano, Moltó, \& Mañes, 2004). The maximum limits (ML) for OTA have been set by European Commission Regulation for cereals at $5 \mu \mathrm{g} /$

\footnotetext{
* Corresponding author. Fax: +34 963544954. Lino).

E-mail addresses: crisjua3@uv.es (C. Juan), cmlino@ci.uc.pt (C.M.
}

$\mathrm{kg}$ and for their products at $3 \mu \mathrm{g} / \mathrm{kg}$ (Commission regulation (EC) No. 123/2005).

OTA is produced by Penicillium verrucossum, by Aspergillus ochraceus, and by a low percentage of isolates of the closely related Aspergillus niger (Elmholt \& Rasmussen, 2005). These three groups of species differ in their ecological niches, in the commodities affected, and in the frequency of occurrence in different geographical regions. $P$. verrucossum is the main source of OTA in cereals and cereal products in Europe, it only grows at temperatures below $30{ }^{\circ} \mathrm{C}$ and down to 0.80 water activity (Elmholt \& Rasmussen, 2005).

Nowadays, many consumers prefer organic to nonorganic foods because they are perceived healthier (Lohr, 2001), nonetheless contradictory results have been reported in scientific reference related with safety of organic and 
non-organic foods (Magkos, Arvaniti, \& Zampelas, 2006). In general, organic practices are thought to reduce the risk of plant infection by pathogens. However, there is some evidence that the reduced use of fungicides may lead to a greater contamination by mycotoxins in organic food (Finamore et al., 2004; Tinker, 2000). Furthermore, environmental conditions such as improper storage, including high temperature, poor drying conditions, and elevated moisture, which are often associated with organic agricultural, may cause fungi survival and promote the development of their metabolites in cereal grains (Frisvald \& Samson, 1991).

Organic farming in Spain began in the end of the 1970s, with small farms, and it was basically promoted by young people coming from the cities. According to a study from 2005 of "Organic Farming in Europe" by Eurostat, in 2002 the organically farmed area reached a total of 4.9 million hectares (ha) in the European Union of 15 member states (EU-15), that is $3.8 \%$ of the total utilised agricultural area of the EU-15. In Spain, in 2003, the total cereals crop area was 6.6 million ha and the organic area percent was $1.5 \%$, while in Portugal, with 450968 ha of cereals crop area, the organic area percentage was $6.6 \%$. This share of organic area cultivation is the highest of the EU-15. Approximately $80 \%$ of the organic Mediterranean crops are exported mainly into central and northern European countries (Rohner-Thielen, 2005).

Jorgensen (2005), Biffi et al. (2004), Czerwiecki, Czajkowska, and Witkowska-Gwiazdowska (2002a), and Anselme et al. (2006) found highest OTA values in organic cereal samples from Denmark, Italy, Poland, and Belgium, respectively. However, results may vary greatly accordingly to the type of crop and mycotoxin in study, being some organic foods reported as less or equally contaminated compared to non-organic food. In Poland, Czerwiecki, Czajkowska, and Witkowska-Gwiazdowska (2002b) found several OTA levels in ecological and conventional different types of cereals.

The objective of this work was to study the incidence of OTA in organic and non-organic cereals and cereal products obtained from Spain and Portugal, and evaluate the daily intake of OTA in the two populations.

\section{Materials and methods}

\subsection{Chemicals}

OTA crystalline material was purchased from Sigma (St. Louis, MO, USA) with purity grade $\geqslant 98 \%$. Stock standard solution with a concentration of $500 \mu \mathrm{g} / \mathrm{ml}$, held for less than three months, was prepared in methanol, kept in security conditions at $-20^{\circ} \mathrm{C}$, and wrapped in aluminum foil, due to OTA breaking down under UV light. Standard working solutions were prepared by appropriate dilution in the same solvent and were stored in glasstopped tubes at $-20{ }^{\circ} \mathrm{C}$.

Methanol, acetonitrile and hydrochloric acid (37\%) were supplied by Merck (Darmstadt, Germany), formic acid
(98-100\%) was from Scharlau (Barcelona, Spain). Deionised water $(8 \mathrm{M} \Omega \mathrm{cm}$ resistivity) was obtained from a Milli-Q water purification system (Millipore, Bedford, MA, USA). Chromatographic solvents and water were degassed for 20 min using a Branson 5200 (Branson Ultrasonic Corp., CT, USA) ultrasonic bath.

Bulk C8 solid phase and nylon acrodisk $(0.45 \mu \mathrm{m})$ were from Análisis Vínicos (Tomelloso, Spain).

\subsection{Sampling}

A total of 83 cereal samples, including wheat, maize, oats, barley, rye, rice and spelt, were collected between April and November 2005 from different markets and supermarkets from Valencia, in Spain, and Coimbra, in Portugal. From the total analyzed samples, 45 were from Spain and 38 from Portugal.

All samples were stored in sealed plastic bags and kept in a dark and dry place. The samples were divided with a subsample divider. A $200 \mathrm{~g}$ subsample was milled and collected in a plastic bag and stored under the same conditions until analysis.

\subsection{Extraction procedure}

OTA was analyzed according to the method reported by Blesa et al. (2004) with slight modifications. Cereal samples $(200 \mathrm{~g})$ were prepared using a food processor and mixed thoroughly. An aliquot $(2.5 \mathrm{~g})$ was placed into a $50 \mathrm{ml}$ mortar and gently blended with $1.5 \mathrm{~g}$ of the solid phase (C8), for $5 \mathrm{~min}$, using a pestle to obtain a homogeneous mixture. This mixture was introduced into a $100 \mathrm{~mm} \times$ $9 \mathrm{~mm}$ i.d. glass column with a coarse frit (No. 2) and covered with a plug of silanized glass wool. OTA was eluted with $20 \mathrm{ml}$ methanol-formic acid (99:1, v/v) using a vacuum manifold. The eluate was concentrated to $3 \mathrm{ml}$ with a gentle stream of $\mathrm{N}_{2}$ at $45^{\circ} \mathrm{C}$, filtered through a nylon acrodisk $(0.45 \mu \mathrm{m})$, and centrifuged at $5000 \mathrm{rpm}$ for $10 \mathrm{~min}$. The extract was filtered again and concentrated to $0.5 \mathrm{ml}$ with $\mathrm{N}_{2}$ at $45^{\circ} \mathrm{C}$.

\subsection{Liquid chromatography and fluorescence detection}

A Shimadzu SCL-6 A liquid chromatography system (Kyoto, Japan) equipped with two LC-6A pumps, a Rheodyne Model 7125 injector ( $20 \mu \mathrm{L}$ loop) and an SRF-535 fluorescence detector were used. A Luna $\mathrm{C}_{18}$ column $(5 \mu \mathrm{m}, 150 \times 4.6 \mathrm{~mm}$ ID) was employed with a mobile phase consisting of methanol-formic acid $0.1 \mathrm{M}(70: 30 \mathrm{v} / \mathrm{v})$ at a flow rate of $0.7 \mathrm{ml} / \mathrm{min}$. Detection of OTA was carried out using 333 and $460 \mathrm{~nm}$, wavelengths for excitation and emission, respectively.

\subsection{Recoveries}

For recovery studies, $2.5 \mathrm{~g}$ of rice, wheat, barley, rye, oats and maize were spiked for three replications at 1 
and $10 \mathrm{ng} / \mathrm{g}$, and allowed to stand for $15 \mathrm{~min}$ at room temperature before extraction.

\subsection{Confirmation procedure}

The identity of OTA was confirmed by methyl ester formation according to Zimmerli and Dick (1995). Briefly, this technique consisted of adding $2.5 \mathrm{~mL}$ of methanol and $0.1 \mathrm{~mL}$ of concentrated hydrochloric acid to $200 \mu \mathrm{L}$ of OTA residue. The vial was closed and kept overnight at room temperature. The reaction mixture was evaporated to dryness and the residue redissolved in mobile phase. Finally, $20 \mu \mathrm{L}$ was analyzed using LC-FD as described above.

\subsection{Statistical analysis}

Database management and statistical analysis were performed with SPSS 10.0 Microsoft Windows version. The differences in the OTA levels between organic and nonorganic samples, and Portuguese and Spanish samples were tested with the $\chi^{2}$ test. $P \leqslant 0.05$ (two-tailed) was considered to be statistically significant. For statistical analysis, when the concentration was below the limit of quantification (LOQ) it was set to $50 \%$ of that limit.

\section{Results and discussion}

OTA recoveries obtained from cereals spiked at 1 and $10 \mathrm{ng} / \mathrm{g}$ ranged $69-85 \%$ and $78-89 \%$, respectively with relative standard deviation (RSD) of 4.30 and 3.66, respectively. The limits of quantification and detection were 0.19 and $0.05 \mathrm{ng} / \mathrm{g}$, respectively. The results reflected the extraction of OTA using $2.5 \mathrm{~g}$ of sample and $1.5 \mathrm{~g}$ of $\mathrm{C} 8$ solid phase, which gave clean chromatogram profiles (Fig. 1). The RSD obtained was according to the European specification (Commission Directive No. 2002/26/EC).

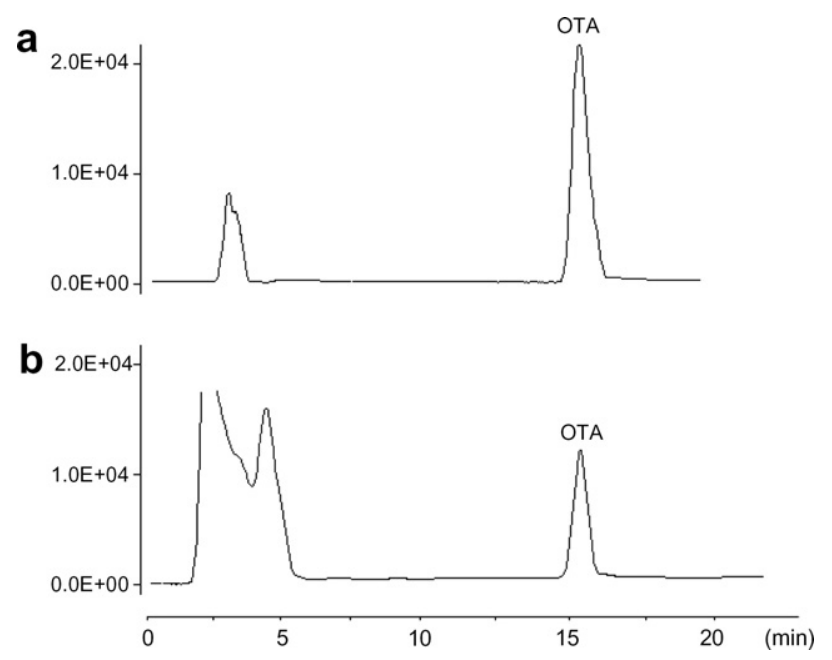

Fig. 1. (a) Chromatogram of a standard solution with $50 \mathrm{ng} / \mathrm{ml}$ of OTA $(\mathrm{RT}=15.8 \mathrm{~min})$; (b) chromatogram of a sample fortified with $10 \mathrm{ng} / \mathrm{g}$.
A total of 83 samples were analyzed, from which 42 were organic and 41 non-organic cereals. In Spain and Portugal, the consumption and production of organic rice, wheat and maize is higher than oats, barley, rye and spelt (FAO/ITC/ CTA, 2001), therefore different number of samples were collected for each kind of cereal.

The results obtained from the analysis of the OTA levels in the samples are presented in Table 1.

OTA was detected in 18 out of 83 samples $(22 \%)$. The range of OTA in the analyzed samples was $0.20-27.10 \mathrm{ng} /$ $\mathrm{g}$, and the mean level was $0.83 \mathrm{ng} / \mathrm{g}$. Trucksess, Giler, Young, White, and Page (1999) found levels higher than $0.03 \mathrm{ng} / \mathrm{g}$ in 56 out of 383 wheat samples, and in 11 out of 103 barley samples from United States. In this study four wheat samples and one barley sample were above the ML established for OTA. MacDonald, Prickett, Wildey, and Chan (2004) analyzed 320 cereals from UK and 52 were contaminated in OTA, which 11 exceeding the ML. Biffi et al. (2004) analyzed OTA in 211 cereal products, the found levels were lower than the legal limit ( $3 \mathrm{ng} / \mathrm{g})$, and ranged from 0.012 to $2.23 \mathrm{ng} / \mathrm{g}$. In the SCOOP-2 report, the mean content of OTA in cereal grains in the EU was 0.27, 0.60, $0.30,0.17$ and $0.19 \mathrm{ng} / \mathrm{g}$ in wheat, rye, barley, maize and oats, respectively (Jorgensen, 2005). Park, Chung, and Kim (2005) observed in Korean samples that wheat flour samples contained OTA levels lower than $0.5 \mathrm{ng} / \mathrm{g}$, and nine samples of polished rice were above the ML established for cereal grains intended to human consumption. A survey study from Ethiopia showed that from 110 samples of barley and wheat, the frequency was $26.2 \%$ and $23.4 \%$, and the mean concentration were $6.1 \mathrm{ng} / \mathrm{g}$ and $14.9 \mathrm{ng} / \mathrm{g}$, respectively (Ayalew, Fehrmann, Lepschy, Beck, \& Abate, 2006). In Morocco the average contamination of maize, wheat, barley and rice were $1.08,0.42,0.17$ and $4.15 \mathrm{ng} / \mathrm{g}$, respectively (Zinedine et al., 2005, 2007). The results obtained from the analysis of organic and non-organic cereals showed that $12 \%$ of non-organic cereals $(n=42)$ and $32 \%$ of organic cereals $(n=41)$ were contaminated with OTA (Table 1). Moreover, the mean concentration of organic cereals was higher than that of non-organic cereals, $1.64 \mathrm{ng} / \mathrm{g}$ vs $0.05 \mathrm{ng} / \mathrm{g}$, with significant difference ( $P$ value of 0.000 ). Fig. 2 shows the chromatograms of two naturally contaminated organic and non-organic cereal samples. This study showed that six organic samples exceeded the ML established for cereals $(5 \mathrm{ng} / \mathrm{g})$. This may be a consequence of organic production, since it involves varied cultivation practices, limited use of non-synthetic fertilizers, pesticides, conditioners of low solubility and no use of genetically modified organisms and/or any products derived from such organisms, giving a wide margin for probable fungi proliferation and mycotoxin production. Elmholt and Rasmussen (2005) pointed that the problems in organic cereals were most likely correlated to a late harvest and high moisture content of the grain, which were not properly handled in the post-harvest. Therefore, becomes easier to achieve the optimal environmental conditions needed to the growth of ochratoxigenic fungi. 
Table 1

Incidence, mean concentration $(\mathrm{ng} / \mathrm{g})$, and range $(\mathrm{ng} / \mathrm{g})$ of OTA in analyzed samples

\begin{tabular}{|c|c|c|c|c|c|c|c|c|c|c|}
\hline \multirow[t]{2}{*}{ Sample } & & \multicolumn{3}{|l|}{ Total } & \multicolumn{3}{|c|}{ Non-whole cereals } & \multicolumn{3}{|c|}{ Whole cereals } \\
\hline & & Incidence & $\begin{array}{l}\text { Mean } \pm \mathrm{SD} \\
(\mathrm{ng} / \mathrm{g})\end{array}$ & $\begin{array}{l}\text { Range } \\
(\mathrm{ng} / \mathrm{g})\end{array}$ & Incidence & $\begin{array}{l}\text { Mean } \pm \mathrm{SD} \\
(\mathrm{ng} / \mathrm{g})\end{array}$ & $\begin{array}{l}\text { Range } \\
\text { (ng/g) }\end{array}$ & Incidence & $\begin{array}{l}\text { Mean } \pm \mathrm{SD} \\
(\mathrm{ng} / \mathrm{g})\end{array}$ & $\begin{array}{l}\text { Range } \\
\text { (ng/g) }\end{array}$ \\
\hline \multirow[t]{8}{*}{ Organic } & $\begin{array}{l}\text { Wheat } \\
(n=11)\end{array}$ & $4 / 11$ & $0.84 \pm 3.13$ & $0.27-7.97$ & $2 / 7$ & $1.18 \pm 2.90$ & $0.27-7.97$ & $2 / 4$ & $0.32 \pm 3.70$ & $0.30-7.60$ \\
\hline & $\begin{array}{l}\text { Maize } \\
(n=5)\end{array}$ & $2 / 5$ & $0.54 \pm 0.83$ & $0.80-1.90$ & $1 / 3$ & $0.63 \pm 1.34$ & 1.90 & $1 / 2$ & $0.4 \pm 0.56$ & 0.80 \\
\hline & Oat $(n=5)$ & $1 / 5$ & $0.50 \pm 1.10$ & 2.50 & $0 / 2$ & $<$ LOQ & $<\mathrm{LOQ}$ & $1 / 3$ & $0.83 \pm 1.25$ & 2.50 \\
\hline & $\begin{array}{l}\text { Barley } \\
(n=4)\end{array}$ & $0 / 4$ & $<\mathrm{LOQ}$ & $<\mathrm{LOQ}$ & $0 / 2$ & $<\mathrm{LOQ}$ & $<\mathrm{LOQ}$ & $0 / 2$ & $<\mathrm{LOQ}$ & $<\mathrm{LOQ}$ \\
\hline & Rice $(n=9)$ & $4 / 9$ & $2.57 \pm 3.43$ & $2.10-7.60$ & $2 / 4$ & $2.41 \pm 3.60$ & $2.10-7.60$ & $2 / 5$ & $2.70 \pm 3.73$ & $5.9-7.54$ \\
\hline & Rye $(n=5)$ & $1 / 5$ & $5.42 \pm 12.10$ & 27.10 & $0 / 2$ & $<\mathrm{LOQ}$ & $<\mathrm{LOQ}$ & $1 / 3$ & $9.03 \pm 15.65$ & 27.10 \\
\hline & $\begin{array}{l}\text { Spelt } \\
(n=2)\end{array}$ & $1 / 2$ & $1.10 \pm 1.50$ & 2.20 & $0 / 0$ & $<\mathrm{LOQ}$ & $<\mathrm{LOQ}$ & $1 / 2$ & $1.10 \pm 1.50$ & 2.20 \\
\hline & $\begin{array}{l}\text { Total } \\
(n=41)\end{array}$ & $13 / 41$ & $1.64 \pm 4.78$ & $\begin{array}{l}<\mathrm{LOQ}- \\
27.10\end{array}$ & $5 / 20$ & $0.99 \pm 2.40$ & $\begin{array}{l}<\mathrm{LOQ}- \\
7.97\end{array}$ & $8 / 21$ & $2.25 \pm 6.28$ & $\begin{array}{l}<\mathrm{LOQ}- \\
7.10\end{array}$ \\
\hline \multirow[t]{9}{*}{$\begin{array}{l}\text { Non- } \\
\text { organic }\end{array}$} & $\begin{array}{l}\text { Wheat } \\
(n=10)\end{array}$ & $5 / 10$ & $0.22 \pm 3.20$ & $0.20-0.90$ & $2 / 6$ & $0.12 \pm 0.20$ & $0.20-0.50$ & $3 / 4$ & $0.37 \pm 1.12$ & $0.20-0.90$ \\
\hline & $\begin{array}{l}\text { Maize } \\
(n=6)\end{array}$ & $0 / 6$ & $<\mathrm{LOQ}$ & $<\mathrm{LOQ}$ & $0 / 6$ & $<\mathrm{LOQ}$ & $<\mathrm{LOQ}$ & $0 / 0$ & $<\mathrm{LOQ}$ & $<\mathrm{LOQ}$ \\
\hline & Oat $(n=7)$ & $0 / 7$ & $<\mathrm{LOQ}$ & $<\mathrm{LOQ}$ & $0 / 5$ & $<\mathrm{LOQ}$ & $<\mathrm{LOQ}$ & $0 / 2$ & $<\mathrm{LOQ}$ & $<\mathrm{LOQ}$ \\
\hline & $\begin{array}{l}\text { Barley } \\
(n=4)\end{array}$ & $0 / 7$ & $<\mathrm{LOQ}$ & $<$ LOQ & $0 / 3$ & $<$ LOQ & $<\mathrm{LOQ}$ & $0 / 1$ & $<\mathrm{LOQ}$ & $<\mathrm{LOQ}$ \\
\hline & $\begin{array}{l}\text { Rice } \\
(n=12)\end{array}$ & $0 / 4$ & $<\mathrm{LOQ}$ & $<\mathrm{LOQ}$ & $0 / 7$ & $<\mathrm{LOQ}$ & $<\mathrm{LOQ}$ & $0 / 4$ & $<$ LOQ & $<$ LOQ \\
\hline & Rye $(n=2)$ & $0 / 12$ & $<\mathrm{LOQ}$ & $<\mathrm{LOQ}$ & $0 / 2$ & $<\mathrm{LOQ}$ & $<\mathrm{LOQ}$ & $0 / 0$ & $<\mathrm{LOQ}$ & $<\mathrm{LOQ}$ \\
\hline & $\begin{array}{l}\text { Spelt } \\
(n=1)\end{array}$ & $0 / 2$ & $<\mathrm{LOQ}$ & $<\mathrm{LOQ}$ & $0 / 1$ & $<\mathrm{LOQ}$ & $<\mathrm{LOQ}$ & $0 / 0$ & $<\mathrm{LOQ}$ & $<\mathrm{LOQ}$ \\
\hline & $\begin{array}{l}\text { Total } \\
(n=42)\end{array}$ & $5 / 42$ & $0.05 \pm 0.15$ & $\begin{array}{l}<\text { LOQ- } \\
0.90\end{array}$ & $2 / 30$ & $0.02 \pm 0.20$ & $\begin{array}{l}<\mathrm{LOQ}- \\
0.50\end{array}$ & $3 / 12$ & $0.13 \pm 0.15$ & $\begin{array}{l}<\text { LOQ- } \\
0.90\end{array}$ \\
\hline & $\begin{array}{l}\text { Total } \\
(n=83)\end{array}$ & $18 / 83$ & $0.83 \pm 1.12$ & $\begin{array}{l}<\mathrm{LOQ}- \\
27.10\end{array}$ & $7 / 50$ & $0.41 \pm 1.25$ & $\begin{array}{l}<\mathrm{LOQ}- \\
7.97\end{array}$ & $11 / 33$ & $1.48 \pm 1.65$ & $\begin{array}{l}<\text { LOQ- } \\
27.10\end{array}$ \\
\hline
\end{tabular}

SD: standard deviation.

LOQ: limit of quantification.

Recently in a critical review of the literature about safety of organic food, Magkos et al. (2006) compared the last studies on the OTA incidence in organic and conventional cereals and cereal products, and observed that only in three out of 12 investigations, the OTA contamination in organic was higher than in conventional analyzed samples, while the others presented similar levels. These studies were performed by Jorgensen (2005), Biffi et al. (2004) and Czerwiecki et al. (2002a), being the highest value found in a spelt flour sample from organic agriculture $(0.816 \mathrm{ng} / \mathrm{g})$ (Biffi et al., 2004).

In our study, the OTA frequency in whole-grain cereal was higher than in non-whole-grain cereal ( $33 \%$ vs $14 \%$ ), and the highest OTA level was found in an organic sample of whole-grain rye $(27 \mathrm{ng} / \mathrm{g})$. These results are in agreement with a study of Scudamore, Banks, and MacDonald (2003) where the scouring in whole wheat removed OTA up to $44 \%$, once a high proportion exists in the bran fraction. On the other hand, Biffi et al. (2004), in cereals and derivatives from Italian market, detected the highest level of OTA in spelt whole flour.
In wheat and rice, the OTA incidence was higher than that of other analyzed cereals, followed by maize. ML was exceeded in three rice samples with 5.90, 7.54 and $7.60 \mathrm{ng} / \mathrm{g}$ of OTA, in two wheat samples with 7.6 and $7.97 \mathrm{ng} / \mathrm{g}$, and in a rye sample with $27.10 \mathrm{ng} / \mathrm{g}$. Biffi et al. (2004) and Lombaert et al. (2003) studied the occurrence of OTA in rice and rice products from Italy and rice-based baby cereals from Canada and Italy. The levels of OTA were quite low $(<1 \mathrm{ng} / \mathrm{g})$ as compared to our results. Also Pena, Cerejo, Lino, and Silveira (2004) studied 42 rice samples from Portugal, and the presence of OTA was found in six samples at concentrations ranging from 0.09 to $3.52 \mathrm{ng} / \mathrm{g}$, while Leblanc, Tard, Volatier, and Verger (2005) estimated the mean OTA in French rice in $0.25 \mathrm{ng} / \mathrm{g}$.

Rice and wheat are cereals with high consumption and production in Portugal and Spain. According to the Agricultural Bulletin Board on Data Collection, Dissemination and Quality of Statistics (ABCDQ) Production notes of FAO in 2004, the production of rice and wheat during 2000 in Portugal was 149000 and 352519 Mt, respectively, 


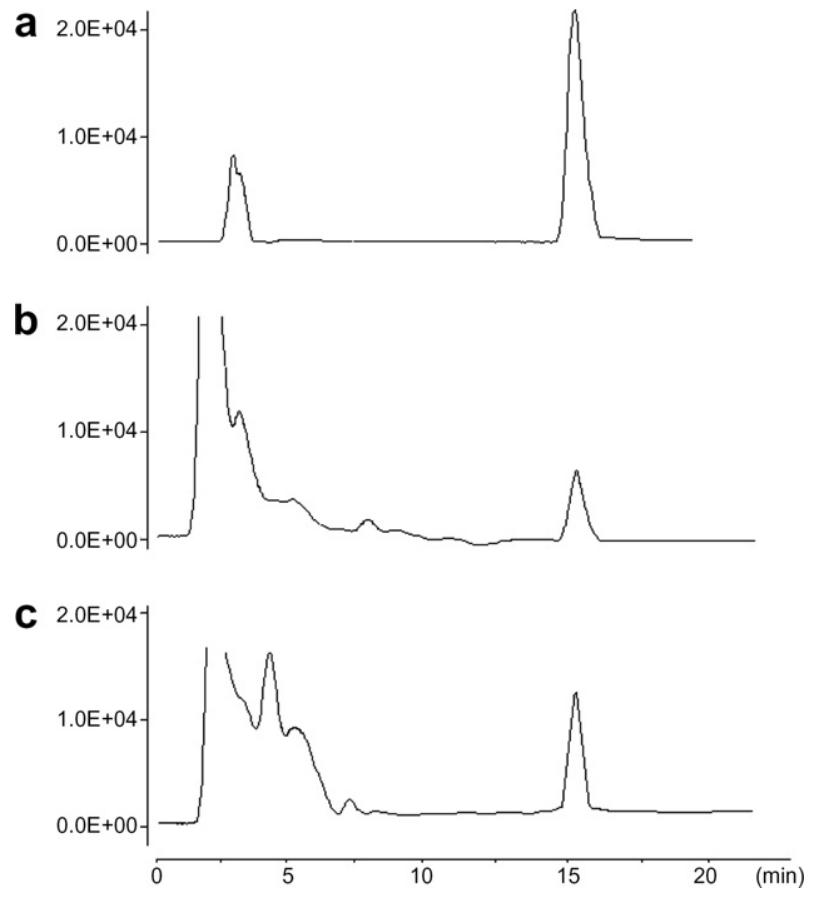

Fig. 2. (a) Chromatogram of a standard solution with $50 \mathrm{ng} / \mathrm{ml}$ of OTA $(\mathrm{RT}=15.8 \mathrm{~min})$; (b) chromatogram of an extract of organic wheat containing $1 \mathrm{ng} / \mathrm{g}$; (c) chromatogram of a positive non-organic wheat with $0.7 \mathrm{ng} / \mathrm{g}$.

and in Spain was $797800 \mathrm{Mt}$ for rice and $7333100 \mathrm{Mt}$ for wheat (FAO/ITC/CTA, 2001).

According to a statistic study of consumption from FAO Statistics Division, in Portugal, the per capita daily calorie intake from cereals are distributed by rice and wheat with 183 and 745, respectively, and the values from Spain are 79 and 636, respectively (FAO/ITC/CTA, 2001).

According to the source of samples, it was observed that $27 \%$ of Spanish samples and $16 \%$ of Portuguese samples were contaminated (Table 2). The mean concentration of OTA was higher in Spanish samples than Portuguese, $0.93 \mathrm{ng} / \mathrm{g}$ vs $0.64 \mathrm{ng} / \mathrm{g}$, respectively. Significant differences were found, $P=0.000$.

The OTA range and average contamination for each analyzed sample in each country is presented in Table 3.

\subsection{Daily intake}

The dietary intake of OTA from the cereal consumption was estimated based on the analyzed samples. The cereal consumption data of Spain and Portugal were obtained from Ministerio de Agricultura Pesca y Alimentación (MAPA, 2004) and from Instituto Português do Consumidor (2005), respectively. A study of cereal consumption by MAPA suggests that the daily intake of cereals in Spain is $240 \mathrm{~g} / \mathrm{day}$, and since the mean OTA level was $0.93 \mathrm{ng} / \mathrm{g}$, and assuming an adult body weight (bw) of $60 \mathrm{~kg}$, the daily intake of OTA in Spain is $3.72 \mathrm{ng} /$ $\mathrm{kg}$ bw/day. In Portugal, since the consumption is $350 \mathrm{~g} /$ day, and the mean OTA level is $0.64 \mathrm{ng} / \mathrm{g}$, the daily intake of OTA is $3.44 \mathrm{ng} / \mathrm{kg} \mathrm{bw} /$ day. The obtained values are below to the OTA tolerable daily intake (TDI) estimated by the European Commission's Scientific Committee on Food (SCF, $5 \mathrm{ng} / \mathrm{kg}$ bw/day) and four times lower than the TDI established by the Joint FAO/WHO Expert Committee on Food Additives (JECFA) (14 ng/kg bw/ day). The daily intake of OTA through cereals samples from Spain and Portugal were the 74.4 and $68.8 \%$ of TDI estimated by SCF.

In comparison with estimated OTA daily intake in Italy and France from consumption of contaminated cereals showed lower values $3.08 \mathrm{ng} / \mathrm{kg}$ bw/day and $2.2 \mathrm{ng} / \mathrm{kg}$ bw/day, respectively (Biffi et al., 2004; Leblanc et al., 2005). However, in other study the estimated PDI for

Table 2

Frequency and OTA levels of Spanish and Portuguese analyzed samples

\begin{tabular}{lllll}
\hline Source of sample & Positive samples & Frequency $(\%)$ & Range of OTA $(\mathrm{ng} / \mathrm{g})$ & Mean $(\mathrm{ng} / \mathrm{g})$ \\
\hline Spain $(n=45)$ & 12 & 27 & $0.2-27.10$ & 0.93 \\
Portugal $(n=38)$ & 6 & 16 & $0.27-7.97$ & 0.64 \\
\hline
\end{tabular}

Table 3

Average and range of OTA for each analyzed matrix in each country

\begin{tabular}{|c|c|c|c|c|c|c|c|}
\hline \multirow[t]{2}{*}{ Sample } & \multicolumn{3}{|c|}{ Incidence } & \multicolumn{2}{|c|}{ Average of OTA $(\mathrm{ng} / \mathrm{g})^{\mathrm{a}}$} & \multicolumn{2}{|c|}{ Range of OTA (ng/g) } \\
\hline & Total & Spain & Portugal & Spain & Portugal & Spain & Portugal \\
\hline Wheat & $9 / 21$ & $7 / 13$ & $2 / 8$ & 1.20 & 1.03 & $0.20-0.90$ & $0.27-7.97$ \\
\hline Maize & $2 / 11$ & $1 / 6$ & $1 / 5$ & 0.32 & 0.16 & 1.90 & 0.80 \\
\hline Oats & $1 / 12$ & $0 / 6$ & $1 / 6$ & n.d. & 0.42 & n.d. & 2.50 \\
\hline Barley & $0 / 8$ & $0 / 5$ & $0 / 3$ & n.d. & n.d. & n.d. & n.d. \\
\hline Rice & $4 / 21$ & $2 / 9$ & $2 / 12$ & 1.49 & 0.80 & $5.90-7.52$ & $7.60-2.10$ \\
\hline Rye & $1 / 7$ & $1 / 4$ & $0 / 3$ & 6.77 & n.d. & 27.10 & n.d. \\
\hline Spelt & $1 / 3$ & $1 / 2$ & $0 / 1$ & 1.10 & n.d. & 2.20 & n.d. \\
\hline Total & $18 / 83$ & $12 / 45$ & $6 / 38$ & 0.93 & 0.64 & $0.20-27.10$ & $0.27-7.97$ \\
\hline
\end{tabular}

n.d.: no detected.

${ }^{\text {a }}$ Average was calculated with total number of each matrix sample for country. 
Korean population ranged from 0.8 to $4.1 \mathrm{ng} / \mathrm{kg}$ bw/day (Park et al., 2005).

\section{Conclusions}

The high incidence and mean concentration of OTA in organic cereals and in Spanish samples reinforce the idea of a vigilant attitude in order to prevent human intake of OTA from foods and the necessity to use of good practices in cereal cultivation, harvesting, transport, processing stage, and storage will minimize the final OTA content in cereals and consequently in cereal products.

The OTA daily intake values are below the TDI proposed levels for both countries but for Spain and Portugal these quantities represent the $74.4 \%$ and $68.8 \%$ of TDI estimated by SCF an alarming percent when the source of OTA would be from other foods.

\section{Acknowledgements}

This work was supported by Integrated Actions Programmes between Portugal and Spain, No. E-1/05 and HP04-69, respectively, and by Spanish Ministry of Science and Technology (AGL-2003-01407). C. Juan thanks the Spanish Ministry of Education and Science for a Research Grant (BI4-40). The authors are also gratefully recognized to Tiago L. Morais for the statistical analysis.

\section{References}

Anselme, M., Tangni, E. K., Pussemier, L., Motte, J.-C., Van Hove, F., Schneider, Y.-J., et al. (2006). Food Additives and Contaminants, 23(9), 910-918.

Ayalew, A., Fehrmann, H., Lepschy, J., Beck, R., \& Abate, D. (2006). Mycopathologia, 162, 57-63.

Biffi, R., Munari, M., Dioguardi, L., Ballabio, C., Cattaneo, A., Galli, C. L., et al. (2004). Food Additives and Contaminants, 21(6), 586-591.

Blesa, J., Berrada, H., Soriano, J. M., Moltó, J. C., \& Mañes, J. (2004). Journal of Chromatography A, 1046, 127-131.

Commission Directive. (2002). Commission Directive 2002/26/EC. Official Journal of the European Communities, L 75/38-43. 16.3.

Commission regulation (EC) No. 123/2005 of 26 January (2005) amending regulation (EC) No. 466/2001 as regards ochratoxin A. Official Journal of the European Union, L25:3-5.

Czerwiecki, L., Czajkowska, D., \& Witkowska-Gwiazdowska, A. (2002a). Food Additives and Contaminants, 19(11), 1051-1057.

Czerwiecki, L., Czajkowska, D., \& Witkowska-Gwiazdowska, A. (2002b). Food Additives and Contaminants, 19(5), 470-477.

Elmholt, S., \& Rasmussen, P. H. (2005). Mycopathologia, 159, 421-432.

FAO/ITC/CTA. (2001). (World markets for organic fruits and vegetables) Organic food and beverage: world supply and major European markets (UNCTAD/WTO International Trade Centre, 1999). $<$ www.fao.org/organicag/fap-e.htm $>$.

Finamore, A., Serena, M., Britti, M. R., Bellovino, D., Gaetani, S., \& Mengheri, E. (2004). Journal of Agricultural and Food Chemistry, 52, 7425-7431.

Frisvald, J. C., \& Samson, A. (1991). Mycotoxins produced by species of Penicillium and Aspergillus occurring in cereals. In J. Chelkwski (Ed.), Cereal grain (pp. 441-476). Amsterdam, The Netherlands: Elsevier Science Publishers.

IARC (1993). In IARC monographs on the evaluation of carcinogenic risks to humans: Some naturally occurring substances; food items and constituents, heterocyclic aromatic amines and mycotoxins (pp. 489-521). Geneva: International Agency for Research on Cancer.

Instituto Português do Consumidor. (2005) <http://www.consumidor.pt/ loja_novo/includes/content/pao_inf_comp.inc $>$. [consult on 8.11.2005].

Jorgensen, K. (2005). Food Additives and Contaminants(supp 1), 26-30.

Leblanc, J. C., Tard, A., Volatier, J. L., \& Verger, P. (2005). Food Additive and Contaminants, 22(7), 652-672.

Lohr, L. (2001). Factors affecting international demand and trade in organic food products. In A. Regmi (Ed.), Changing structure of global food consumption and trade (pp. 67-79). Washington, DC: USDA/ Economic Research Service.

Lombaert, G. A., Pellaers, P., Roscoe, V., Mankotia, M., Neil, R., \& Scott, P. M. (2003). Food Additives and Contaminants, 20, 494-504.

MacDonald, T. J., Prickett, K., Wildey, B., \& Chan, D. (2004). Food Additives and Contaminants, 21(2), 172-181.

Magkos, F., Arvaniti, F., \& Zampelas, A. (2006). Critical Reviews in Food Science and Nutrition, 46(1), 23-56.

Ministerio de Agricultura Pesca y Alimentación (MAPA). (2004). $<$ www.mapa.es/es/agricultura/agricultura.htm $>$ (consult on December 2005).

Park, J. W., Chung, S., \& Kim, Y. (2005). Journal of Agricultural and Food Chemistry, 53, 4637-4642.

Pena, A., Cerejo, F., Lino, C., \& Silveira, I. (2004). Analytical and Bioanalytical Chemistry, 382, 1288-1293.

Rohner-Thielen, E. (2005). Statistics in focus. Agriculture. Organic farming in Europe. Eurostat, 31/2005.

Scudamore, K. A., Banks, J., \& MacDonald, S. J. (2003). Food Additives and Contaminants, 20(12), 1153-1163.

Tinker, P. B. H. (2000). Shades of Green, A Review of UK Farming Systems. Conclusion (pp 92-97). Stoneleigh, UK: Royal Agricultural Society of England.

Trucksess, M. W., Giler, J., Young, K., White, K. D., \& Page, S. W. Journal of AOAC International, 82(1), 85-89.

Zinedine, A., Brera, C., Elakhdari, S., Catano, C., Debegnach, F., Angelini, S., et al. (2005). Food Control, 17(11), 868-874.

Zinedine, A., Soriano, J. M., Juan, C., Mojemmi, B., Molto, J. C., Bouklouze, A., et al. (2007). Incidence of ochratoxin A in rice and dried fruits from Rabat and Sale area Morocco. Food Additives and Contaminants, 24(3), 285-291.

Zimmerli, B., \& Dick, R. (1995). Determination of ochratoxin A at the ppt level in human blood, serum, milk and some foodstuffs by high-performance liquid chromatography with enhanced fluorescence detection and immunoaffinity column cleanup: methodology and Swiss data. Journal of Chromatography, B, 666, 85-99. 